\title{
THE ROLE OF THE JUDICIARY FIGHTING "THE RIGHT TO BE IGNORANT" IN ENVIRONMENTAL ADMINISTRATIVE PROCEEDINGS IN CHILE
}

\begin{abstract}
Chilean laws provide adequate public access to environmental information, but also provide exemptions from disclosure. The impairment and the trade secret exemptions can hinder transparency and public input when required in environmental-related adjudication and rule-making proceedings. Even they may be misused to avoid blame, therefore information not covered by these exemptions, yet sensitive for any reason, may be unduly withheld. While there is a public transparency watchdog, the Council for Transparency, issues regarding public access to information in environmental-related adjudication and rule-making proceedings can be reviewed by the Environmental Courts. This Article outlines some aspects of the Chilean general transparency and administrative procedures, and the environmental transparency rules, as related to public input in environmental adjudication and rule-making proceedings. Then it shows how the Judiciary has fought "the right to be ignorant".
\end{abstract}

\section{Keywords}

environment - environmental governance - administrative decision making - right to know - transparency - environmental courts

* Jose A. Hernandez Riera, LL.M. (c), J.D., University of Chile, School of Law (Chile). Judicial Clerk, 3rd Environmental Court, Valdivia (Chile). Associate Professor of Environmental Law \& International Relations, St. Sebastian University, School of Law, Valdivia (Chile), e-mail: jhernandezr@docente.uss.cl. All quotes of Chilean laws, 


\section{INTRODUCTION}

Environmental affairs are a complex issue of political discourse, ranging over very diverse topics, such as conservation, pollution, and natural resources management. But in our ordinary lives, as in the political realm, there are competing interests regarding the use of and impact on the environment by human activities.

As such, Principle 11 of the 1972 Stockholm Declaration ${ }^{1}$ stated concern for both environmental protection policies and the attainment of development goals in developing countries; but it contained no principle on transparency or access to environmental information. However, Recommendation 97 advocated that arrangements be made by the UN Secretary-General to set an information programme to associate the public with environmental management and control, providing a means of stimulating active participation by citizens; and Recommendation 103 advocated for necessary steps to be made by all governments not to invoke environmental concerns as an excuse for discriminatory trade policies, and to adopt appropriate compensation measures if environmental-based trade restrictions were adopted ${ }^{2}$.

But even once the Cold War ideological confrontation had waned, underdevelopment endured ${ }^{3}$, and Principle 11 of the 1992 Rio Declaration endorsed its 1972 predecessor, by asserting that environmental policies and regulations "should reflect the environmental and developmental context to which they apply", as some policies adopted by some countries "may be of unwarranted economic and social cost to other countries, in particular developing countries" ${ }^{4}$. Nonetheless, Principle 10 was different;

regulations, academic articles or papers, are translated by the author unless stated otherwise.

${ }^{1}$ U.N. Doc. A/CONF.48/14/ Rev.1 (16 June 1972).

2 Recommendation 103, U.N. Doc. A/CONF.48/14/ Rev.1 (16 June 1972).

${ }^{3}$ See generally Vicky Randall \& Robin Theobald, Political Change and Underdevelopment: a Critical Introduction to Third World Politics, Second Edition, PALGRAVE: MacMillan Press, 1998, also Sati U. Fwatshak, The Cold War and the Emergence of Economic Divergences: Africa and Asia compared, in Toyin Falola \& EmmaNuel Mbah ed., Contemporary Africa Challenges and Opportunities, Palgrave: MacMillan, 2014, p. 89-127.

${ }^{4}$ U.N. Doc. A/CONF.151/126/Rev.1 (12 August 1992). 
it was an enormous leap forward as compared with Recommendation 97, by stating that each individual shall have "appropriate access to information that is held by public authorities concerning the environment", an "opportunity to participate in decision-making processes", and "effective access to judicial and administrative proceedings" for retrieving environmental information and to protect participation ${ }^{5}$.

Both declarations showed that competing interests were ubiquitous in environmental affairs, as well as in the advocacy of procedural rights for access to information and for providing public input in decision-making. As such, Chapter 8 of the 1993 Agenda 21 encouraged all governments "to develop or improve mechanisms to facilitate the involvement of concerned individuals, groups and organizations in environmental decisionmaking at all levels", by "ensuring transparency of, and accountability for, the environmental implications of economic and sectoral policies", as well as "access by the public to relevant information, facilitating the reception of public views and allowing for effective participation" ${ }^{\prime \prime}$.

Also, Chapter XI of the Plan of Implementation, attached to the 2002 Johannesburg Declaration 7 , states among its goals enhancing the participation and effective involvement of civil society and other relevant stakeholders in implementing Agenda 21, and promoting transparency and broad public participation; and, at a national level, it advocates for strengthening institutional frameworks for sustainable development, particularly by providing the necessary infrastructure and promoting transparency, accountability, and fair administrative and judicial institutions.

It is clear that environmental debate, whether in politics or policy, at the national or international level, needs information for better decision-making and execution. It is necessary to set policy goals, appraise outcomes, and eventually hold accountable those responsible for its design and execution. But the general public debate is far more complex, and often politicians are worried about improving economic

${ }^{5}$ U.N. Doc. A/CONF.151/126/Rev.1 (12 August 1992).

${ }^{6}$ U.N. Division for Sustainable Development, Agenda 21, U.N. Dept. of Public Information (1992), p. 65-66.

7 U.N. Doc. A/CONF.199/20 (4 September 2002). 
performance, reducing unemployment rates, and securing adequate provision of public services, among many other competing concerns under budgetary constraints.

Our elected politicians and appointed officials want to be elected, reelected, appointed, or confirmed, to have their public policy swiftly adopted and executed, and if they are successful, to claim credit for it ${ }^{8}$. Accordingly, every setback must be avoided or lessened, a costly mistake recorded must be kept hidden by all affordable means, if not eventually released in a data smog ${ }^{9}$, and once public, inserted in blame games ${ }^{10}$. Yet, secrecy is necessary to achieve other policy goals: national security or law enforcement issues are typical examples of such goals.

Therefore, expressions like open government and transparency are embedded in the modern democratic discourse related to access to information. They involve a political nature, its symbolism better understood by appealing to its antonyms: close government and secrecy, hinting that governments may tend to keep ordinary people ignorant of public affairs. Though many countries have enacted laws on access to information held by governments, they all encompass disclosure

${ }^{8}$ Hood argues that to all political actors, the politics of credit-claiming is identical to the politics of blame-avoidance, because credit can be expected to increase their chances of re-election, reappointment, promotion, and favourable repute during or even after their lifetimes. See Christopher Hood, The Blame Game, Princeton University Press 2011.

${ }_{9}$ Roberts argues that the struggle over access to information is over distribution of political power, but contends that since the $1946 \mathrm{APA}$, and more importantly since the 1967 FOIA, there is a phenomenon of indiscriminate release of government information, citizens being unable to keep up with this sprawling mass of information, becoming lost in "data smog". See Alasdair Roberts, Blacked Out: Government Secrecy in the Information, Cambridge University Press 2006.

${ }^{10}$ Hood argues that the politics of blame-avoidance triumphs over "good governance" bromides; its mechanisms are subtle, found deep in the way organizations work and their members behave; its triumph being unintended, as it goes against the declared thrust of reform policies; and more importantly, blame avoidance is imperative in the behaviour of appointed officials and elected politicians. He even argues that officeholders have recognizable reasons for concern with management of blame, as elected politicians will manage it to keep their chances of re-election, managers will do it to keep their chances of promotion, bonuses, even of not being sacked, and so on. See Christopher Hood, The Blame Game, Princeton University Press 2011. 
exemptions. Information not covered by these exemptions, yet sensitive for any reason, may be withheld by misusing exemptions ${ }^{11}$.

An amazing British television series of the 1980s, "Yes, Minister", framed this situation in a sharp and funny way ${ }^{12}$. A senior official for the fictional Minister for Administrative Affairs, Bernard Woolley - played by Derek Fowlds - is ready to execute the "open government" policy advocated by the newly formed government; yet, two colleagues disagree, Sir Humphrey Appleby - played by Nigel Hawthorne - and Sir Arnold Robinson - played by John Nettleton. In a witty dialogue all positions regarding transparency are revealed:

Sir Bernard Woolley: What's wrong with Open Government? I mean why shouldn't the public know more about what's going on?

Sir Arnold Robinson: Are you serious?

Sir Bernard Woolley: Well, yes, sir I mean, it is the minister's policy after all.

Sir Arnold Robinson: My dear boy, it is a contradiction in terms: you can be open or you can have government.

Sir Bernard Woolley: But surely the citizens of a democracy have a right to know...

Sir Humphrey Appleby: No. They have a right to be ignorant. Knowledge only means complicity in guilt; ignorance has a certain dignity.

Sir Bernard Woolley: $\quad$ But if the Minister wants Open Government... Sir Humphrey Appleby: You just don't give people what they want if it's not good for them! You give Brandy to an alcoholic?

Sir Arnold Robinson: If people don't know what you're doing, they don't know what you're doing wrong.

Sir Humphrey Appleby's "right to be ignorant" epitomizes unaccountability. Thus, transparency laws are useful to hold officials accountable, by helping people to watch for government misconduct or malfeasance,

${ }^{11}$ Hood, citing Sulitzeanu-Kenan and Hood, and Roberts, argue that restricting information is a possible way to manage blame, and it can adopt different forms, from official secrecy to central management of embarrassing information, and even by being immensely transparent, hiding blameworthy information in data smog or releasing it promptly to reduce chances of spotting before some key accountability forum. See Christopher Hood, The Blame Game, Princeton University Press, 2011.

12 It was in its first episode, "Open Government", first broadcasted in 25 February 1980. 
and to assert with enough evidence as to influence the political process. But as the previous dialogue shows, officials are frequently worried about the consequences of their actions or lack thereof, hence secrecy is always a possibility to avoid accountability.

Chile delayed its legislative action for general transparency for too long, but this it is rather understandable. In Latin America, Chile was a stable country, though heavy political unrest ensued in the 1920s and early 1930s ${ }^{13}$. Since the 1960s, academics have advocated the enactment of a statute regulating general administrative procedures, with no political echo $^{14}$, as instability was renewed and fueled by the Cold War ${ }^{15}$. Chilean society engaged in a proxy conflict ${ }^{16}$, which climaxed with the 1973 coup d'état, ending the democratically elected Allende administration, starting the Pinochet regime.

The military junta was poised to reshape Chilean administrative governance, and in 1973 it set the National Committee on Administrative Reform to investigate and recommend improvements for the structure and practice of the existing executive departments and agencies ${ }^{17}$. One recommendation was to adopt a general administrative procedure statute, including access to judicial review. ${ }^{18}$ In the late 1970s and early 1980s several drafts were discussed, but never approved ${ }^{19}$.

${ }^{13}$ See John Hickman, News from the End of the Earth: A Portrait of Chile, Hurst \& Co. (1998). The 1924 coup d'état ended the democratically elected first Alessandri administration, and the 1932 coup d'état ended the democratically elected Montero administration.

${ }^{14}$ See Comisión de Derecho Administrativo, Cuartas Jornadas Chilenas de Derecho Público, "Revista de Derecho Universidad de Concepción” 1966, vol. 135, p. 75.

15 See Tanya Harmer, Allende's Chile and the Inter-American Cold War, University of North Carolina Press, 2011.

${ }^{16}$ CIA operations in Chile until 1973 drew widespread interest from jurists, but KGB interference was also significant. Ulianova and Fediakova show some mechanisms used by the USSR to steadily finance the Chilean Communist Party since 1955. See Olga Ulianova and Eugenia Fediakova, Algunos aspectos de la ayuda financiera del Partido Comunista de la URSS al comunismo chileno durante la Guerra Fría, "Estudios Públicos" 1998, vol. 113, issue 75.

17 See Carlos Huneeus, The Pinochet Regime, Lynne Rienner (2007).

18 See Comisión Nacional para la Reforma Administrativa, Chile hacia un nuevo destino (1976), p. 54. At least on paper, the Junta was concerned about excessive red tape and delays in administrative decision-making.

19 See Jaime Jara, La garantía jurídica de la unidad del procedimiento administrativo en la Ley No 19880, 70 “Revista de Derecho Público” 2015, vol. 70, p. 287. 
In the 1990s, with the return to democracy, Chile engaged in a transitional process, though many keystone economic laws and regulations adopted by the military junta were essentially kept intact ${ }^{20}$. Efforts to enact a general administrative procedure statute resumed, now with strong demands for transparency and public participation ${ }^{21}$. In 1992, under the Aylwin administration, a bill was introduced to Congress to such effect, but it failed to gain political momentum ${ }^{22}$. However, progress was made gradually, first by passing the 1999 Administrative Rectitude Act (1999 ARA $)^{23}$, then the long-awaited 2003 Administrative Procedure Act (2003 APA $)^{24}$, and then the 2008 Freedom of Information Act (2008 FOIA) ${ }^{25}$.

Since the 2000s, Chile has endeavoured to create a modernization agenda, its apex being its OECD membership achieved in 2010 under the first Bachelet administration. Chile seems determined to increasingly execute the best public governance policies to improve economic and social welfare ${ }^{26}$. Environmental policies and governance appear as key components to achieve these purposes ${ }^{27}$.

${ }^{20}$ See C. Sapelli, The Political Economy of the Chilean Transition to Democracy, "Cuadernos de Economía" 2000, vol. 37, p. 537. Also, Jorge Nef, The Chilean Model, Fact and Fiction, "Latin American Perspectives" 2000, vol. 30, issue 5, p. 16.

${ }^{21}$ See R. Mendoza, Notas sobre el acceso a la documentación administrativa (acerca de la publicidad, la transparencia y el secreto) [Notes on access to administrative documentation (about advertising, transparency and secrecy)], "Revista de Derecho Público" ["Public Law Magazine"] 1996, vol. 59, p. 243.

22 See N. Enteiche, La excepcional autotutela ejecutiva de los actos administrativos en Chile [The exceptional executive self-rule of administrative acts in Chile], "Revista de Derecho Universidad Católica del Norte" ["Law Magazine Universidad Católica del Norte” 2014, vol. 21, p. 137.

2336538 D.O. 2, 14 December 1999, as Law Nº 19653.

2437570 D.O. 2, 29 May 29 2003, as Law N 19880.

2539142 D.O. 3, 20 August, 2008, as Law N²0285.

${ }^{26}$ The 2003 U.S. - Chile Free Trade Agreement stated in its preamble that both countries are resolved to "create new employment opportunities and improve working conditions and living standards in their respective territories", "implement this Agreement in a manner consistent with environmental protection and conservation; to promote sustainable development", "conserve, protect, and improve the environment, including through managing natural resources in their respective territories and through multilateral environmental agreements to which they are both parties", and "preserve their flexibility to safeguard the public welfare". Pub. L. 108-77, 114 Stat. 1526.

${ }^{27}$ See OECD/WB/UN, Incorporating Green Growth and Sustainable Development Policies 
As one of many legal reforms required to successfully bid for OECD membership, Chile enacted the 2010 Environmental Governance Reform Act (EGRA) ${ }^{28}$, setting up a new executive department, the Ministry of Environmental Affairs (acronym MMA in Spanish) - as the rule-making authority - and two new independent agencies, the Service of Environmental Assessment (acronym SEA in Spanish) - as the integrated environmental permitting authority - and the Superintendency of Environmental Affairs (acronym SMA in Spanish) - as the integrated enforcement authority. This statute also enhanced transparency and access to environmental information. Moreover, the 2012 Environmental Courts Act $(\mathrm{ECA})^{29}$ set three special courts with subject matter jurisdiction to review environmental administrative decisions, and to adjudicate civil litigation over environmental damages ${ }^{30}$.

This Article aims to display how the Chilean courts have eased access to environmental information since 2012, when the new environmental governance started. Part I provides a tour d'horizon of the current Chilean general transparency law, as related to laws on access to environmental information. Part II describes three administrative procedures in which active transparency is mandatory - notice-and-comment rulemaking, notice-and-comment permitting adjudication, and enforcement adjudication - and identifies some problems arising from its design. Part III shows how the Chilean courts have eased access to environmental information. Part IV concludes with some remarks.

into Structural Reform Agendas, prepared for G20 Summit (2012). Also, OECD, Recommendation of the Council on Regulatory Policy and Governance (2012), calling for commitment at the highest political level to an explicit whole-of-government policy for regulatory quality, with "clear objectives and frameworks for implementation to ensure that, if regulation is used, the economic, social and environmental benefits justify the costs, the distributional effects are considered and the net benefits are maximized".

2839570 D.O. 3, 26 January 2010, as Law N²0417.

2940299 D.O. 1, 28 January 2012, as Law N²0600.

${ }^{30}$ Regarding its territorial jurisdiction, the three courts are: 1st Environmental Court, from Arica to Coquimbo regions; 2nd Environmental Court, from Valparaiso to Maule regions; and 3rd Environmental Court, from Biobio to Magallanes regions. 


\section{Chilean general transparency laws}

As this section will set the reader in a comparative study perspective, it must be stressed that there is often no exact match between concepts belonging to different legal traditions, thus, some misunderstanding is expected.

As stated before, Chile has endeavoured to create a modernization agenda, and among many competing political issues, progress was made on transparency by passing the 1999 ARA, significantly improved by the 2008 FOIA. The 1999 ARA had severe flaws in terms of transparency, as for instance, proactive disclosure was absent, wide discretionary reasons for exemption to reactive disclosure were adopted, and information could be declared classified no only by law, but also by regulation ${ }^{31}$. Therefore, rule-making was abused to enhance secrecy.

But in 2004, the Committee of Experts of the Follow-up Mechanism for the Inter-American Convention against Corruption issued its first final report for Chile, calling for amending the 1999 ARA, and pointing subtly to repealing the rule-making on secrecy ${ }^{32}$. Also, the Controller General blocked some proposed regulations by arguing their unreasonable wide scope to declare confidentiality, rendering useless the 1999 ARA $^{33}$. In 2006, a landmark decision of the Inter-American Court of Human Rights,

31 See A. Muñoz, Transición a la democracia, políticas de probidad y mecanismos internacionales de protección de derechos humanos: el caso de Chile [Transition to democracy, probity policies and international mechanisms for the protection of human rights: the case of Chile], [in:] J. Zalaquett, A. Muñoz (ed.), Transparencia y Probidad Pública, Estudios de Caso en América Latina [Transparency and Public Probity, Case Studies in Latin America], Andros: 2008, p. 113-130.

32 SG/MESICIC/doc.89/03 rev.4. A summarized translation: "under the 1999 ARA, agencies can deny a disclosure request based on exemptions established by rule-making, thus allowing the undermining of transparency rights established by law. This does not mean that we consider such regulations as illegal, as such determination is outside our duties, but we want to bring attention about the desirability of enhancing the right to access information established by law, by leaving its limitations to be established only by law."

${ }_{33}$ Comptroller General, legality assent decision number 34118, 22 July 2005, over Resolution 62/2005 issued by the National Commission for Environmental Affairs, rulemaking on transparency. 
Claude Reyes et al. v. Republic of Chile, condemned Chile for not fulfilling its obligation to adopt domestic legal provisions to make effective the right to access public information as construed within article 13 of the 1969 American Convention on Human Rights, which embodies the freedom of thought and expression ${ }^{34}$.

This decision provided political momentum for passing the 2008 FOIA, being an extraordinary step forward to more transparency, just by repealing the rule-making on secrecy, as the passing of any law to set new exemptions of disclosure would require a supermajority ${ }^{35}$. And the 2010 EGRA provided further transparency regarding environmental information.

\section{TRANSPARENCY AS REOUIRED BY THE 2008 FOIA}

The 2008 FOIA set transparency in two ways. Firstly, there is proactive disclosure, as certain information must be regularly and permanently disclosed by the agency. Secondly, there is reactive disclosure, as certain information not subject to proactive disclosure must be released by the agency, if requested.

The 2008 FOIA define agency as any executive department or agency, regional executive body, military or constabulary body, municipality, government-owned or government-controlled corporation ${ }^{36}$. It also has a broad definition of record, defined as any information obtained, prepared, or processed using public funds, or held by an agency in any format, regardless of date, origin or classification ${ }^{37}$. Furthermore, it established an official transparency watchdog, the Council for Transparency, to review negative decisions of disclosure adopted by agencies, if a complaint over it is filed promptly.

${ }^{34}$ Claude Reyes et al. v. Republic of Chile, Merits, Reparations, and Costs, Judgment, Inter-Am. Ct. H.R. (ser. C) No. 151 (2006).

${ }^{35}$ Law $\mathrm{N}^{\circ} 20285$, art. $1^{\text {th }}$, tit. IV, art. 5b, as principle of freedom of information.

${ }^{36}$ Law $\mathrm{N}^{\circ} 20285$, art. $1^{\text {st }}$, tit. I, art. 2.

${ }^{37}$ Law $\mathrm{N}^{\circ} 20285$, art. $1^{\text {st }}$, tit. II, art. 5. 


\section{A. Proactive disclosure}

Agencies are required to release and permanently display in their websites all laws and regulations related to their functions, internal organizational structure - detailing the functions and responsibilities of units, guidelines for administrative petitions and requests when applicable, and even every final administrative adjudication order. Agencies are also required to release and display their economic information, such as annual budgets, levels of budgetary execution and financial audits, and lists including details of their staff members - including names, positions and wages recipients of grants, assistances, and subsidies awarded by the agency including names and amounts - and procurement or outsourcing contracts $^{38}$. As stated before, any negative decision on a request to release undisclosed information subject to proactive disclosure can be reviewed by the Council for Transparency.

\section{B. ReActive disclosure}

Agencies are required to release any information requested, if it is not covered by an exemption ${ }^{39}$. No statement of purposes is needed to file a request $t^{40}$. Information exempted from disclosure is exceptional. Agencies can deny disclosure requests under the impairment exemption, by asserting that release may impair due performance of its functions, particularly by risking law enforcement efforts ${ }^{41}$, decision-making procedures, or by distracting significant resources to process and deliver the requested information. Equally, denial of disclosure is allowed if the information requested is declared classified as required by law ${ }^{42}$, is deemed sensitive for national security purposes ${ }^{43}$, or is protected under

\footnotetext{
${ }^{38}$ Law $\mathrm{N}^{\circ} 20285$, art. $1^{\text {th }}$, tit. VII, art. 7.

${ }^{39}$ Law $\mathrm{N}^{\circ} 20285$, art. $1^{\text {th }}$, art. $11 \mathrm{~d}$, as principle of maximum disclosure.

${ }^{40}$ Law $N^{\circ} 20285$, art. $1^{\text {th }}$, art. $11 \mathrm{~g}$, as principle of non-discrimination.

${ }^{41}$ Law $\mathrm{N}^{\circ} 20285$, art. $1^{\text {th }}$, art. 21.1.

${ }^{42}$ Law $\mathrm{N}^{\circ} 20285$, art. $1^{\text {th }}$, art. 21.5.

${ }^{43}$ Law $\mathrm{N}^{\circ} 20285$, art. $1^{\text {th }}$, arts. 21.3, 21.4.
} 
trade secrecy and personal privacy ${ }^{44}$. Likewise, as active disclosure, any negative decision on a request to release information exempted from proactive disclosure can be reviewed by the Council for Transparency ${ }^{45}$.

\section{AdMINISTRATIVE PROCEEDINGS UNDER THE 2003 APA}

While not directly dealing with the right to know, the 2003 APA set a general administrative procedure where some transparency issues may arise, both from the perspective of the interested party in its direct relation with the governmental agencies, and of thirds parties or the general public. Therefore, it is necessary to introduce some of its main procedural features.

The 2003 APA does not clearly distinguish rule-making and adjudication, yet its tenets can be construed to identify those addressing each one, and those addressing common features. Chilean jurists recognize both rule-making and adjudication procedures ${ }^{46}$. They argue that rulemaking is employed to formulate, amend, or repeal rules (reglamentos in Spanish), defining rules as legal norms enacted by agencies, duly authorized and, as required by statute, normally of general applicability and future effect, and mandatory and enforceable over persons, parties, and agencies ${ }^{47}$. It is upheld that rule-making is also used to formulate, amend,

${ }^{44}$ Law $\mathrm{N}^{\circ} 20285$, art. $1^{\text {th }}$, art. 21.2.

${ }^{45}$ Law $\mathrm{N}^{\circ} 20285$, art. $1^{\text {th }}$, art. 24.

46 See E. Cordero, Las normas administrativas y el sistema de fuentes [Administrative rules and the system of sources], "Revista de Derecho Universidad Católica del Norte" Issue 17, 2010, p. 21. Also, J. Precht, Valor jurídico de las directivas presidenciales, programas ministeriales, circulares e instrucciones de servicio [Legal value of presidential directives, ministerial programs, circulars and service instructions], "Revista Chilena de Derecho Issue" 1989, vol. 16, p. 465; C. Carmona, Un nuevo estadio en la relación Ley-Reglamento: el ámbito del reglamento [A new stage in the Law-Regulation relationship: the scope of the regulation], "Revista de Derecho Público" 2001, vol. 16, p. 154; and K. Cazor, Problemas teóricos en torno a las potestades normativas y la necesaria redefinición de la reserva legal en el Estado constitucional chileno [Theoretical problems around the regulatory powers and the necessary redefinition of the legal reserve in the Chilean constitutional State], 19 "Ius et Praxis" 2013, vol. 19, p. 35.

47 According to Cordero "rules are statements of will issued in exercise of public powers, though with general and permanent effects", "they are binding over agencies, officials and, specially, persons". See Cordero supra note 46 at p. 32. 
or repeal organizational rules (directivas in Spanish), only mandatory over agency officials ${ }^{48}$. They also contend that adjudication is used to formulate final administrative decisions (acto administrativo terminal in Spanish), defining them as written decisions made by an agency, as authorized by statute, normally being of individual applicability and immediate effect, mandatory and enforceable only over persons, with some precedential value in subsequent proceedings ${ }^{49}$.

The 2003 APA is lex generalis, so it must yield before any lex specialis. But if some aspect of lex specialis does not expressly depart from lex generalis, the latter is applied ${ }^{50}$. This is quite important, as newer statutes dealing with regulatory issues have departed from the 2003 APA without expressly superseding or modifying it, thus some problems may arise to construct implicit repeal. As such, Chilean environmental laws are lex specialis in some rule-making and adjudication proceedings.

\section{A. RULE-MAKING PROCEEDINGS}

As stated before, the 2003 APA does not contain specific sections dealing with rulemaking, yet some provisions are clearly applicable to it, such as those related to publishing regulations. Nevertheless, some flaws can be pointed out immediately. The statute does not require the giving of general notice of proposed rule-making, thus, often the public remain ignorant about it. However, some companies become aware of such intent because the agency requests from them information on certain related issues to draft the regulation. Also, it provides for a discretionary public input period ${ }^{51}$. However, if public input is provided, the agency must

${ }^{48}$ According to Cordero, "organizational rules are enacted by the agency's head in exercise of its housekeeping powers... to achieve sound performances from the agency". See Cordero supra note 46 at p. 33.

49 See G. Camacho, El concepto de acto administrativo [The concept of an administrative act], [in"] G. Bocksang, J. Lara (ed.), Procedimiento administrativo y contratación pública [Administrative procedure and public procurement], Thomson Reuters 2013, p. 63-90.

${ }^{50}$ Law $\mathrm{N}^{\circ} 19880$, art. 1, “...This act establishes the administrative procedure basics. If other acts establish specific administrative procedures, this act will be applied as suppletory".

${ }^{51}$ Law N ${ }^{\circ} 19880$, art. 39, "The agency in charge of the administrative procedure may adopt a public input period, if required". 
response to all issues raised ${ }^{52}$. And clearly, the final rule must be subject to general notice to become binding.

Nonetheless, the 2011 Public Participation Act ${ }^{53}$ modified the 1986 State Organization $\mathrm{Act}^{54}$, by including provisions to deal with general public input in rule-making procedures. Regrettably, it leaves it up to each executive department or agency to enact a general rule on the issue, declaring which rule-making procedures will comprise a public input stage. As such, the general rule issued by the MMA limits this stage to those procedures where is mandatory by law ${ }^{55}$. But the general rule issued by the Ministry of Public Health is comprehensive, ordering a public input stage in every rule-making proceeding ${ }^{56}$.

\section{B. AdJUDICATION PROCEEDINGS}

The 2003 APA does contain specific sections dealing with adjudication. In fact, its main concern is on adjudication proceedings, describing requirements to commence, hear, and decide, and also dealing with ancillary matters. The hearing stage is of significant importance, as the presiding employee (instructor in Spanish) must assess evidence, draft a decision on fact and law, and submit it to the agency's final decision maker ${ }^{57}$.

While the 2003 APA does provide for evidence to be submitted in any form, thus including oral evidence, there is a widespread reluctance to conduct oral hearings, based on restrictive interpretation by the agencies. Therefore, testimonies, expert opinions, and cross-examination are

${ }^{52}$ Law N 19880, art. 39, "For every comment, the agency shall provide a reasoned response, which can be the same for all those raising substantially same issues".

5339887 D.O. 2, 16 February 2011, as Law N²0500.

5432640 D.O. 1, 5 December 1986, as Law Nº 18575.

${ }_{55}$ Resolution $\mathrm{N}^{\circ} 601$ (2015), art. 16.

${ }^{56}$ Resolution $\mathrm{N}^{\circ} 31$ (2015), art. VI.

${ }^{57}$ Law $N^{\circ} 19880$, art. 34, "The relevant facts for decision making can be proved by any legally admissible evidence, to be weighted according to sound discretion. If the Agency has not knowledge of the facts alleged by persons, or if it is deemed necessary, the presiding officer shall order a fact-finding period... and will be authorized to deny any evidentiary request only on grounds of irrelevancy or unnecessariness." Yet the final decision-making powers are allocated, except as otherwise expressly provided by statute, on the superior agency authority. 
virtually impossible, and all evidence is submitted in written form. But there are two major flaws; no alternative means of dispute resolution are available, and although it is required that the functions of presiding employees and of employees participating in the decision-making process shall be conducted in an impartial manner, there are no structural conditions to guarantee $i^{58}$.

The 2003 APA does not require exhaustion of all administrative venues for relief before judicial review, nonetheless it provides two optional ways to get redress: to ask for administrative or for judicial review. If judicial review is chosen, the administrative review is permanently unavailable; if administrative review is chosen instead, after exhaustion of all administrative remedies the judicial review is still available ${ }^{59}$. But in some specific statutes there is no option, and the exhaustion of administrative remedies is mandatory ${ }^{60}$. Also, the Chilean courts have interpreted that judicial review is only available to final administrative orders, yet exceptionally other decisions can be reviewed, mainly when they are tantamount to early termination of proceedings, or when they cause defencelessness, and it is always required to show injury-in-fact in order to have standing ${ }^{61}$.

58 The 1989 Civil Service Act (33479 D.O. 1, 23 September 1989, as Law Nº 18834) defines tenured staff as the number of civil servants permanently assigned to an agency, the civil servant track being only available to them; but it also defines hired staff as the number of civil servants temporarily assigned to an agency, on a calendar year basis, though their contracts can be renewed. Therefore, any agency will have mix of tenured and hired employees, e.g., as per the 2018 Appropriation Law, the SMA is authorized to pay for 200 employees, but only 24 are tenured, thus near $90 \%$ of its staff are hired. All staff are subject to performance rating on a yearly basis by an internal rating commission, hired staff can be dismissed at any time or not renewed.

59 Law N 19880 , art. 54.

${ }^{60}$ As Law $N^{\circ} 19300$, tit. II, para. 2, art. 20, amended by Law $N^{\circ} 20417$, art. $1^{\text {st. }}$ Final orders on environmental permitting cannot be directly appealed before an Environmental Court; first they must be appealed before the administrative review board, namely the Committee of Ministries.

${ }^{61}$ Law N ${ }^{\circ} 19880$, Ch. I, art. 15. 


\section{OUTLINE OF CHILEAN ENVIRONMENTAL TRANSPARENCY RULES}

\section{General Disclosure AS REOUUIRED BY THE 2010 EGRA}

As stated before, the 2010 EGRA established a new executive department, the MMA, and two new independent agencies, the SEA and the SMA. The reorganization included bolstering the existing information platforms and launching new ones, as will be shown below.

The 2010 EGRA also includes a new section in the 1994 General En vironmental Act (GEA), dealing with access to environmental information as a right ${ }^{62}$. It defines what information is classified as environmental information, including a representative $\operatorname{list}^{63}$, but it expressly states that such right to know must be exercised under the 2008 FOIA $^{64}$. It also set two administrative procedures where active transparency is mandatory, related to public input in environmental decision-making.

Firstly, notice-and-comment rule-making proceedings for issuing emission standards for facilities (ESF) or products (ESP), environmental quality standards (EQS), and regional implementation planning for attainment of EQS (RIPAEQS) require a well-defined procedural stage for public comment, and before their commencement, a complete set of information and reports must be released to the public ${ }^{65}$.

Secondly, permitting adjudication for issuing integrated environmental permits (IEP), as required by the 1994 GEA, requires in certain cases, a well-defined procedural stage for public comment, and, before its beginning, a complete set of information and reports must be released to the public, ${ }^{66}$ though some information can be declared classified ${ }^{67}$.

${ }^{62}$ Law $\mathrm{N}^{\circ} 20417$, art. $1^{\text {st }}$, modifying Law $\mathrm{N}^{\circ} 19300$, tit. II, para. 3 bis.

${ }^{63}$ Law $\mathrm{N}^{\circ} 20417$, art. $1^{\text {st }}$, modifying Law $\mathrm{N}^{\circ} 19300$, tit. II, para. 3bis, art. 31bis.

${ }^{64}$ Law $\mathrm{N}^{\circ} 20417$, art. $1^{\text {st }}$, modifying Law $\mathrm{N}^{\circ} 19300$, tit. II, para. 3bis, art. 31quater.

${ }^{65}$ Law $\mathrm{N}^{\circ} 20417$, art. $1^{\text {st }}$, modifying Law $\mathrm{N}^{\circ}$ 19300, tit. II, para. 4, art. 32; para. 5, art. 40 ; para. 6 , art. 44 .

${ }^{66}$ Law $\mathrm{N}^{\circ} 20417$, art. ${ }^{\text {st }}$, modifying Law $\mathrm{N}^{\circ} 19300$, tit. II, para. 3.

${ }_{67}$ Law $\mathrm{N}^{\circ} 20417$, art. $1^{\text {st }}$, modifying Law $\mathrm{N}^{\circ} 19300$, tit. II, para. 3, art. 27. 
Nonetheless, enforcement adjudication also requires the granting of access to information to both the defendant and the public, but there is no stage for public comment and it is not properly regarded as a transparency issue. However, as some records can be declared classified under the impairment exemption, issues arise bordering on reactive transparency, as will be shown later. This becomes complicated, as final environmental administrative decisions can be challenged under the 2012 ECA before the respective Environmental Court, ${ }^{68}$ but its decisions can be appealed to the Supreme Court ${ }^{69}$.

\section{A. THROUGH ONLINE INFORMATION PLATFORMS}

Some data in these online information platforms is required to be held and disclosed by two or more enforcement agencies, so they link, redirect, or share their databases if needed to save time and resources. There are five different platforms:

- Nationwide Environmental Information System (NEIS) platform, run by the $\mathrm{MMA}^{70}$. It contains online publication of all environmental-related laws, regulations, final administrative decisions, and treaties ratified by Chile; of every national stateof-the-environment quadrennial report and its database; of all environmental related administrative permits; and to all environmental-related decisions of the Comptroller General and the Judiciary ${ }^{71}$.

- Nationwide Pollutant Release and Transfer Registry (NPRTR) platform, run by the $\mathrm{MMA}^{72}$. It was conceived as a one-stop report system for pollution sources with monitoring, recordkeeping, and reporting obligations, mainly sources releasing pollutants or transferring waste for their treatment or final disposal. However, this platform also contains emission estimates assessed for

\footnotetext{
${ }^{68}$ Law $\mathrm{N}^{\circ} 20600$, art. 17.

${ }^{69}$ Law $\mathrm{N}^{\circ} 20600$, art. 26.

${ }^{70}$ http:// sinia.mma.gob.cl/ [last accessed: 20 June 2018].

${ }^{71}$ Law $N^{\circ} 19300$, art. 31ter.

72 http:/ / www.retc.cl/ [last accessed: 20 June 2018].
} 
other pollution sources, as non-point sources, to put together a comprehensive national pollution inventory ${ }^{73}$.

- Nationwide Environmental Enforcement Information System (NEEIS) platform, run by the $\mathrm{SMA}^{74}$. It contains records related to permits, as the facility's IEP, each specific environmental permit associated with it, all records related with inspections performed in the permittee's facilities, and with its monitoring, recordkeeping, and reporting. It also comprises information related to RIPAEQS, ESF, ESP, and EQS, all records related to all enforcement adjudication proceedings advanced by the SMA, and all environmental-related decisions issued by the Comptroller General and the Judiciary ${ }^{75}$.

- National Permitting Database (NPD) platform, run by the SEA ${ }^{76}$. It contains records related to environmental permits ${ }^{77}$.

- National Environmental Baseline Permitting Database (NEBPD) platform, is also run by the $\mathrm{SEA}^{78}$. It contains records related to the environmental baselines prepared for IEP submissions ${ }^{79}$.

\section{B. NOTICE-AND-COMMENT RULE-MAKING}

In the 2010 EGRA, and previously in the 1994 GEA, the Chilean Congress set a general policy mandate regarding environmental standards and regulations - namely ESF, ESP, EQS and RIPAEQS. It assigns a twofold rule-making authority to the MMA firstly to adopt procedural rules to issue such standards and regulations, and secondly, to adopt these standards and regulations using the procedural rules.

Regarding the procedural rules, the 1994 GEA set some basic features. Among them are mandatory stages to perform scientific research, technical enquiries, and economic analysis, and to submit proposed regulation to

\footnotetext{
${ }^{73}$ Law N $\mathrm{N}^{\circ} 19300$, art. 70p.

${ }^{74}$ http:// snifa.sma.gob.cl/v2 [last accessed: 20 June 2018].

${ }^{75}$ Law $\mathrm{N}^{\circ} 20417$, art. $2^{\text {nd }}$, tit. II, para. 3, art. 31.

${ }^{76}$ http://seia.sea.gob.cl/busqueda/buscarProyecto.php

77 Law $N^{\circ} 20417$, art. $1^{\text {st }}$, modifying Law $N^{\circ} 19300$, tit. Final, para. 6, art. 81b.

${ }^{78}$ http://sea.gob.cl/evaluacion-ambiental/informacion-linea-base-eia

${ }^{79}$ Law N 19300, art. 81c.
} 
public commentary, with all these stages subject to due notice and general publicity requirements ${ }^{80}$. These procedural rules were first set in $1995^{81}$, and repealed and replaced in $2013^{82}$. They are a sort of lex specialis visà-vis the 2003 APA.

Any administrative proceeding to set, review, or repeal environmental standards or regulations begins by public notice of such rule-making intent ${ }^{83}$, consequently it is published in the Official Journal. Such public notice starts a 365-day deadline to issue a draft rule, by performing scientific research, technical enquiry, and economic analysis, in order to release three key records: (i) the draft rule, (ii) its technical report, and (iii) its cost-benefit analysis (CBA) report, including social impacts ${ }^{84}$. The draft rule also requires public notice, therefore starting a 60-day deadline for public input ${ }^{85}$. Once this stage is closed, the MMA has a 120-day deadline to respond to all comments and observations made, and to incorporate those accepted into a new draft rule ${ }^{86}$. Then, it must be submitted to the Council of Ministries for Sustainability for discussion and provisory consent ${ }^{87}$, then to the President of Chile for final consideration and approval ${ }^{88}$.

Nonetheless, as will be shown in Part III, in some rule-making proceedings the MMA has begun and concluded the notice-and-comment stage without releasing the CBA report. This is problematic for both private companies and people, since they may need to reassess the CBA report to be sure of the adequacy of the proposed rule. On one hand, from the companies' standpoint, they need to review the CBA to detect underestimated private costs risking an uninformed decision on a standard that would harm private interests. On the other hand, from the people's standpoint, they need to detect overestimated costs and

\footnotetext{
${ }^{80}$ Law $\mathrm{N}^{\circ} 19300$, arts. 32, 40, 44.

${ }^{81}$ Decrees N 93/1995, ESF-, ESP- and EQS-setting Rules; N 94/1995, RIPAEQSsetting Rules.

${ }^{82}$ Decrees N 38/2012, ESF-, ESP- and EQS-setting Rules; N 39/2012, RIPAEQSsetting Rules.

${ }^{83}$ Decrees $N^{\circ} 38 / 2012$, art. 12; N³9/2012, art. 7.

${ }_{84}$ Decrees $N^{\circ} 38 / 2012$, arts. 13, 15 (CBA); No 39/2012, arts. 8, 9 (CBA).

${ }^{85}$ Decrees $N^{\circ} 38 / 2012$, arts. 16 to 20; N³9/2012, arts. 10 to 12.

${ }^{86}$ Decrees $N^{\circ} 38 / 2012$, art. 21; N³9/2012, art. 13.

87 Decrees $N^{\circ} 38 / 2012$, art. 22; N³9/2012, art. 14.

${ }^{88}$ Decrees $N^{\circ} 38 / 2012$, art. 23; N³9/2012, art. 15.
} 
underestimated social and economic benefits risking a lenient standard passing as normal.

This is an ongoing issue, as for example the primary EQS for criteria pollutant SO2 in ambient air is currently under revision, and in its notice-and-comment stage the CBA report was seriously criticized by private companies for underestimating $\operatorname{costs}^{89}$, and by people accusing overestimation $^{90}$.

\section{NOTICE-AND-COMMENT PERMITTING ADJUDICATION}

In the 2010 EGRA, and before in the 1994 GEA, the Chilean Congress also set a general policy mandate on the issue of environmental permits. It assigned rule-making authority in the MMA to propose and adopt procedural rules to issue IEP, but it allocated the permit adjudication authority to the SEA. Regarding procedural rules for permit adjudication, the 1994 GEA set some basic features, yet much more detailed than in notice-and-comment rule-making. If the planned facilities or activities are listed in the 1994 GEA, they are prohibited unless an IEP is issued.

This being so, there are two permitting procedures with common features to issue IEP. In both procedures, the applicant must ascertain first if its projected action will cause significant impact on the environment. If it does, it must submit an Environmental Impact Study (EIS) to be handled under EIS procedural rules ${ }^{91}$; if not, it must submit an Environmental Impact Declaration (EID) to be handled under EID procedural rules ${ }^{92}$. These rules were first established in $1995^{93}$, and repealed and replaced in $2013^{94}$.

In EID proceedings, the SEA must make public in the Official Journal, on a monthly basis, a list with all EIDs submitted the previous

${ }^{89}$ Comments on the matter were submitted by CODELCO, a state-owned company with primary copper smelters in Ventanas, Chuquicamata, Potrerillos, and Caletones (p. 815-821), ENAMI, a state-owned company with a primary copper smelter in Tierra Amarilla (p. 822-899), and Anglo-American Sur Inc., a privately owned company with a primary copper smelter in Chagres (p. 830-910).

\footnotetext{
90 Comments on the matter were submitted by NGO FIMA (p. 972-977).

${ }^{91}$ Law $\mathrm{N}^{\circ} 19300$, art. 11.

92 Law N ${ }^{\circ} 19300$, art. 10.

93 Decree $N^{\circ} 30 / 1997$, EIAS Rules.

${ }^{94}$ Decree $N^{\circ} 40 / 2012$, EIAS Rules.
} 
month ${ }^{95}$. Moreover, the applicant must advertise its EIS through local radio stations ${ }^{96}$. By default, there is no mandatory notice-and-comment stage; however, if the applicant declared environmental burdens to be caused by its projected action, the agency must open a 20-day term notice-and-comment stage if requested by a third party within a 10-day term running from the official monthly publication ${ }^{97}$.

But in EIS proceedings, the notice-and-comment stage is mandatory, as the applicant must make public its EIS submission in the Official Journal and in regional newspapers ${ }^{98}$, advertise it through local radio stations $^{99}$, and the agency must open a 60 -day term notice-and-comment stage running from the aforesaid official publication ${ }^{100}$.

Nonetheless, while the administrative record must be displayed online, with all its documents, the 1994 GEA allows applicants to request confidentiality under the trade secret exemption. If they encompass information essential to assess environmental impacts, it can defeat the purpose of the mandatory notice-and-comment stage, thus being problematic for environmental transparency. As such, the EIAS Rules award no confidentiality to documents necessary to assess significant environmental impacts or environmental burdens ${ }^{101}$.

\section{DisCLOSURE IN ENFORCEMENT ADJUDICATION UNDER THE 2010 EGRA}

\section{A. Compliance oversight UNDER the 2010 EGRA}

As stated before, the 2010 EGRA set the SMA as the new executive agency dealing with environmental enforcement and compliance activities. But it also launched a somewhat complex compliance oversight system, with partial overlapping of duties among the SMA and existing agencies dealing with specific environmental or sanitary issues. Being so, the SMA

\footnotetext{
95 Law N 19300, art. 30.

96 Law No 19300, art. 30ter.

97 Law $N^{\circ} 19300$, art. 30bis.

98 Law No 19300, art. 28.

99 Law $N^{\circ} 19300$, art. 30ter.

100 Law N 19300, art. 29.

101 Decree $N^{\circ}$ 40/2012, art. 22.
} 
not only directly inspects and oversees facilities, but it also arranges and manages compliance oversight actions among agencies. However, it is the only agency with authority to sanction, and so breaches detected by other agencies are subject to referral ${ }^{102}$.

This complex design is executed via yearly enforcement programmes issued by the SMA, stating compliance actions to be executed by itself and the other agencies. Such programmes are based on specific sets of permits and regulations, such as IEPs, RIPAEQSs and ESFs, and the facilities to be targeted are chosen after a careful planning process, in which they are ranked by their relative non-compliance and environmental risk, determined by their past compliance performance, and the environmental fragility and social sensitivity of their locations. According to the 2010 EGRA, yearly enforcement programmes must disclose the planned number of on-field inspections, data processing of self-reports, and budgetary information related to $i^{103}$.

Even if proceedings to issue sanctions can be commenced only by the SMA, prompted by its Enforcement Division or by referral from another agency, they can also be prompted by a complaint filed by anyone ${ }^{104}$. The 2010 EGRA set that every filed complaint must be swiftly processed, and if it has reasonable evidence of violation, enforcement adjudication proceedings must be started immediately. ${ }^{105}$ This can be quite challenging because it can disrupt the yearly risk-based enforcement programmes.

\section{B. ACCESS TO INFORMATION BY COMPLAINANTS}

If an enforcement adjudication proceeding is prompted by a complaint, the 2010 EGRA states that the complainant is to be considered an interested party, and should therefore be allowed an active role. This may have potentially disruptive effects on the enforcement policy, as they might dispute decisions made by the SMA, such as suspending proceedings, or the final decision itself ${ }^{106}$.

\footnotetext{
${ }^{102}$ Law $\mathrm{N}^{\circ} 20417$, art. $2^{\text {th }}$, art. 59.

103 Law $N^{\circ} 20417$, art. $2^{\text {th }}$, arts. 16, 17.

${ }^{104}$ Law $\mathrm{N}^{\circ} 20417$, art. $2^{\text {th }}$, art. 47.

105 Law N ${ }^{\circ} 20417$, art. $2^{\text {th }}$, art. 21, 47.

106 Law N $\mathrm{N}^{\circ} 20417$, art. $2^{\text {th }}$, art. 21.
} 
These proceedings can only be suspended if, within 10 days after the notice of violation is served, the alleged offender submits a compliance schedule and it is approved by the SMA; eventually the proceedings can be discontinued if a such schedule is promptly and fully executed ${ }^{107}$. Compliance schedules need to include financial information so as to be properly assessed, so the defendant often requests confidentiality of this data, raising transparency issues vis-à-vis complainants. But there are other issues regarding inspection reports, as someone might want to access them to properly file a complaint against a company, while only the SMA and the inspected facilities owners have knowledge about them.

Transparency issues also arise in the handling of complaints. Under the 2010 EGRA, the SMA has a 60-day term running from the filing of a complaint to inform the complainant of its conclusion on the matter ${ }^{108}$. Between 2013 and 2016, the agency received 6,118 complaints, 297 were closed averaging 308 days of processing for each one, 318 were further handed on to enforcement proceedings, and 5,503 were still in unknown status ${ }^{109}$. The SMA's budget and staff are clearly insufficient to duly and promptly deal with complaints within the 60-day term. As almost all complaints are queued in a waiting list by the SMA, they are unwilfully neglected, unless the complainant insists on asking about their whereabouts, or eventually files transparency requests to know how the complaint is being processed ${ }^{110}$. However, such non-disclosure is not due to an ethos of secrecy; it is the outcome of a flawed design of enforcement procedures, coupled with underfunding and understaffing.

\section{ACCESS TO INFORMATION BY OVERSEEN COMPANIES}

Irrespective of how an enforcement proceeding was prompted, the defendant has the right to access all documents related to it after its

107 Law $\mathrm{N}^{\circ} 20417$, art. $2^{\text {th }}$, art. 41.

108 Law N $\mathrm{N}^{\circ} 20417$, art. $2^{\text {th }}$, art. 21.

109 Based on data disclosed by the SMA in its web page http://www.sma.gob.cl/ transparencia/index.html

110 See Luis Cordero et al., Derribando mitos: propuestas para mejorar el acceso a la justicia ambiental en Chile, Espacio Público 2017. 
commencements ${ }^{111}$. This is quintessential to their right to defence and to due process. But before commencement there are restrictions relating to access to some documents of inspection records, arising from some issues affecting both complainants and defendants. These restrictions cannot be properly labelled as transparency issues, yet they are closely related.

Before the commencement of the enforcement proceedings, overseen companies might want to have access to some information collected and processed by the agency. From the company's standpoint, there are no transparency issues over inspection reports - the agency must hand over a copy - nor self-reports - the company itself sends them - but there are issues regarding compliance research reports. These reports are prepared by the Enforcement Division of the SMA, to provide expert evidence by processing, analyzing, and integrating other evidence, such as inspection reports and self-reports. The whole of the evidence is used to decide the commencement of enforcement proceedings.

However, the 2010 EGRA has a statute of repose of 3-years from the date when the violation happened, but had not been detected ${ }^{112}$. From the agency's stance this is not problematical regarding continuing violations, but it is a problem regarding non-continuing violations ${ }^{113}$. Nonetheless, from the defendants' viewpoint, in either case it is worrying since once a breach has been detected, but no notice of violation is served within a reasonable time, with no suspicion of potential violations, they can unwittingly destroy potential evidence to be used on their own behalf.

There are other problems as well; once an enforcement proceeding has commenced, companies may request full disclosure of records to the SMA, as guaranteed by the 2003 APA. To respond, this statute set

${ }^{111}$ Law N 19880, art. 17, "All persons, in their relations with the Administration, have the right to know, at any moment, the status of the proceedings in which they are considered an interested party, and to get a duly authorized copy of all its records...".

112 Law N ${ }^{\circ} 20417$, art. $2^{\text {th }}$, art. 37.

113 As seen from the present, violations can be either non-continuing or continuing. A non-continuing violation started and finished in the past, and it is a single, definitive, and separated action which already happened on a particular date, like not sending a monthly report in a given month, or a discrete discharge of wastewater in a river, violating the ESF. A continuing violation started in the past, but it can be an ongoing one, like failing to put up and run a mandatory add-on emission abatement device or to construct and operate a landfill with a non-compliant geomembrane in its base liner system. 
a 2-day term running from the filing of a request, while the 2008 FOIA set a 20-day term. The SMA has denied the request filed under the 2003 APA on grounds of inappropriateness, stating that it must be filed under the 2008 FOIA. However, filing again under the 2008 FOIA resulted in denial based on exemptions for disclosure, thus forcing companies to request review before the Council for Transparency. This practice was deemed legal by the Comptroller General until recently, wrongly on grounds of statutory interpretation, generalia specialibus non derogant ${ }^{114}$. However, as under the 2012 ECA, the SMA's final administrative decision can be reviewed by the respective Environmental Court, some companies started to access these courts in lieu of the Council of Transparency, as will be shown later.

\section{EASING ACCESS TO ENVIRONMENTAL INFORMATION: THE JUDICIARY'S ROLE}

The issues explained in the previous section showed some administrative practices impairing transparency, but fortunately the Chilean courts have reviewed and reversed some of these wrong decisions. The easing of access to environmental information advanced by the Judiciary is discussed in the following three sub-sections covering notice-andcomment rule-making, notice-and-comment permitting adjudication, and enforcement adjudication.

\section{A. EASING DISCLOSURE IN NOTICE-AND-COMMENT RULE-MAKING}

As stated before, notice-and-comment rule-making under the 2010 EGRA makes a public input stage obligatory, but before its opening three key

${ }^{114}$ In its mandatory opinion $\mathrm{N}^{\circ} 27945$ of 2017, it stated that "the 2008 FOIA set a procedure to grant access to any person to public information upheld by the Administration, while the 2003 APA explicitly protected the right of interested parties in an administrative proceeding to access its records. Hence, the former clearly guarantees the right of interested parties to such access without subordinating its exercise to a special procedure. Being so, it is not acceptable, in order to grant such access, to demand that the interested party filed its request under the 2008 FOIA". 
records must be made public by the MMA: the draft of a proposed environmental standard, its technical report, and its CBA report. But, in some cases this has been ignored and subjected to litigation.

This issue was first taken to the Judiciary in Dougnac v. $M M A^{115}$. In December 2013, the defendant finalized its revision proceeding for the primary EQS for criteria pollutant PM10 in ambient air without changing its 24-hour standard and dropping its 365-day standard. The decision was deemed too lenient by NGOs and townships, therefore in January 2014 they asked for its review and reversal before the 2nd Environmental Court, mainly on substantive grounds.

The plaintiff stated that the administrative proceeding did not collect sufficient evidence so as to reasonably justify the final decision; besides some evidence was introduced after the notice-and-comment stage. In contrast, the defendant stated that it had collected enough evidence and that the evidence could be introduced at any stage if it was relevant. In addition, an amicus brief pointed out some problems with the CBA report, which in their opinion was wrongly introduced after the noticeand-comment stage.

The Court took a hard-look review approach, examining closely the administrative record, and in December 2014 decided that some key documents, including the CBA report, were introduced after the noticeand-comment stage, and reversed and remanded the administrative decision on both procedural and merits grounds. It concluded that there was insufficient evidence to reasonably drop the 365-day standard. This decision was unanimously affirmed by the Supreme Court in September $2015^{116}$.

A similar issue was taken to the Judiciary in Valdivia Development Assoc. v. $M M A^{117}$. In November 2015, the defendant finalized its issuance proceedings of the secondary EQS for surface waters in the Valdivia river basin. Deemed too stringent by companies, in January 2016 they asked for review and reversal before the 3rd Environmental Court, on both procedural and substantive grounds.

\footnotetext{
115 2nd Environmental Court, case number R-22-2014, 16 December 2014.

116 Supreme Court of Justice, case number 1119-2015, 28 January 2015.

117 3rd Environmental Court, case number R-25-2016, 29 September 2016.
} 
The plaintiffs stated that the administrative proceeding did not collect sufficient evidence to reasonably justify the final decision; besides claiming that some key evidence was introduced after the notice-andcomment stage. Particularly, the plaintiffs stated that the introduction of the CBA report rather a long time after the notice-and-comment stage defeated any purpose of this procedural stage. They also contended that the CBA report itself was inadequate. In contrast, the defendant stated that it did collect sufficient evidence, that the relevant evidence could be introduced at any stage, and that the CBA report was adequate.

This Court also took a hard-look review approach, examined closely the administrative records, and in September 2016 decided that some key documents, including the CBA report, were wrongly introduced after the notice-and-comment stage, thus defeating its purpose and damaging transparency; therefore, it reversed and remanded the administrative decision on procedural grounds. Moreover, the Court also concluded that the CBA report, even in its updated version, was inadequate and lacked enough evidence in order to be duly examined. This decision was reviewed and unanimously confirmed by the Supreme Court in July $2017^{118}$. This was an important step on proactive transparency and procedural fairness, as to properly achieve the purpose of the commentand-notice stage, ordering the MMA to introduce on the record all mandatory documents before the beginning of such an important stage and to release them on time.

Since this landmark decision, the MMA has closely complied with all procedural stages, and promptly released all mandatory information. Hopefully further litigation will be based on substantive grounds alone.

\section{B. EASING DISCLOSURE IN NOTICE-AND-COMMENT PERMITTING ADJUDICATION}

As stated before, under the 2010 EGRA notice-and-comment, permit issue adjudication in EIS proceedings has a mandatory public input stage, but in EID proceedings it is required only if a prompt request is made by third

118 Supreme Court of Justice, case number 83344-2016, 26 July 2017. 
parties. It was also stated that although the administrative record must be displayed online, applicants can request confidentiality of technical or financial documents to protect trade secrets. Information essential to assess environmental impacts is not covered by this exemption. However if confidentiality is erroneously granted, it defeats the purpose of the notice-and-comment stage.

A related issue was first taken to the Judiciary in Reiss Greenwood v. SEA ${ }^{119}$. In November 2011, the defendant granted a request for confidentiality, submitted by the Ministry of Public Works, over some information to be submitted in the permitting proceeding over the Route $\mathrm{CH}-66$ project, a highway linking the Central Valley zone (with significant agricultural activity) and San Antonio, the second busiest port in Chile. This data was related to traffic flow estimates used to assess air quality and noise impacts, and it was considered to be trade secrets because they were included in the technical offer made by the company who was awarded the road concession. After granting such request, an EIS was submitted but this data was kept confidential.

In the notice-and-comment stage, the plaintiff made comments doubting the traceability and accuracy of both air quality and noise impacts. Then it petitioned for voiding the administrative proceeding, on the grounds of its being unlawful to grant confidentiality over data necessary to verify if significant environmental impacts, and their mitigation measures, were duly assessed. This petition was refused. Then, the plaintiff filed for judicial review before the 2nd Environmental Court, but a stay order over the administrative proceeding was denied. The defendant resumed the adjudication proceeding and issued the IEP. Then the plaintiff filed an administrative appeal against this final decision before the administrative review board while the decision denying voidance was under judicial review.

The plaintiff stated that the permitting agency must have voided the administrative proceeding because it did not disclose all essential information, as required by 2010 EGRA and EIAS Rules. It argued that confidentiality cannot be granted to records related to assess significant environmental impacts or environmental burdens, because to do so defeats

119 2nd Environmental Court, case number R-5-2013, 16 August 2013. 
the purpose of the notice-and-comment stage, and also the transparency goals of the 2008 FOIA. The defendant asserted that its decision over the confidentiality request was not grounded in the 2010 EGRA, but in the 2008 FOIA, and thus was subject to review by the Council for Transparency; and also contended that the undisclosed data was necessary to assess significant environmental impacts or environmental burdens.

The Court took a hard-look review approach, issued a subpoena duces tecum to get such confidential records, and examined it in-camera. In its August 2013 decision, it concluded that even if the administrative decision over confidentiality was not a final order, it could be reviewed in view of its immediate consequence; and though adopted under the 1994 GEA disclosure exemption alone, it concluded that confidentiality was superfluous because when the EIS application was submitted, the highway concession had already been awarded. But most importantly, the Court stated that when the right to business-related confidentiality was in conflict with the right to fully informed participation in environmental decision-making, the latter must prevail. It concluded so by construing the 1994 EGRA and the EIAS Rules under international law, particularly Principle 10 of the 1992 Rio Declaration. Therefore, it reversed and fully remanded the administrative decision on both substantive and procedural grounds. Unfortunately, this important decision was overruled in a divided vote by the Supreme Court in June 2014, in SEA v. Reiss Greenwood ${ }^{120}$, on procedural grounds, arguing that only final administrative decisions can be reviewed by the Environmental Courts, after the exhaustion of administrative remedies.

Transparency in notice-and-comment permitting adjudication was again taken to the Judiciary in Historical \& Cultural Heritage Defence Committee v. SEA ${ }^{121}$. In September 2014, the SEA issued an IEP based on the EIS submitted by a real estate development company, to construct a 10-story hotel in a coastal protected area in Concon. As required by the 2010 EGRA, the plaintiff exhausted all administrative remedies, and in October 2015 filed for judicial review before the 2nd Environmental Court, regarding concerns over significant impacts on landscape, flora, fauna, and human living conditions from road traffic and tsunami

\footnotetext{
120 Supreme Court of Justice, case number 7451-2013, 26 June 2014.

121 2nd Environmental Court, case number R-86-2015, 6 November 2017.
} 
hazard, overlooked by the SEA. Before deciding on the merits, the Court stated, obiter dictum, that public input in the notice-and-comment stage is not a mere formality, not even a general principle, but a substantive requirement with a correlative duty of the SEA to ease it and to duly address all comments made. It remarked that this twofold duty is imposed not only by the 1994 GEA, but also by Principle 10 of the 1992 Rio Declaration.

Thus, the Court concluded that all records to assess environmental impact must be publicly available for scrutiny before the comment-andnotice stage, otherwise it could render useless the right to know and make pointless the public input stage. Then it took a hard-look review approach again, examined closely the administrative proceeding, and pointed out that some records over significant impacts on landscape, flora, fauna, and human living conditions from tsunami hazard, were absent before the notice-and-comment stage, and therefore it reversed and remanded the administrative decision on both substantive and procedural grounds. This decision was not appealed against to the Supreme Court.

\section{EASING DISCLOSURE IN ENFORCEMENT ADJUDICATION}

As enforcement proceedings can be prompted by complainants, handling complaints has become a highly sensitive management issue for the agency, as is confidentiality of compliance research reports. Regarding complaints, most non-disclosure decision had been challenged before the Council for Transparency.

The landmark administrative decision is Hermosilla v. SMA ${ }^{122}$. In January 2013, Mr. Hermosilla filed a disclosure request to access all complaints filed since December 2012; but the SMA refused stating that once processed to commencement of enforcement proceedings or dismissed, complaints would be be proactively disclosed via the NEEIS platform, and meanwhile are to remain undisclosed under the impairment exemption. Mr. Hermosilla then filed an administrative appeal before the Council for Transparency, but in April 2013 the administrative decision

${ }^{122}$ Council for Transparency, case number C273-13, Apr. 26, 2014. 
was affirmed, although it warned the SMA about delaying the processing of complaints, because the impairment exemption can only be upheld for a reasonable time until adopting the administrative decision.

This delay has become problematic, as showed in Vergara v. SMA ${ }^{123}$, since complainants are unable to know the whereabouts of its complaints. In October 2014, Mr. Vergara filed a disclosure request to access any response regarding a complaint he filed in November 2013; but the SMA refused stating that it was not a proper disclosure request, just a mere inquiry for procedural status. Mr. Vergara then filed an administrative appeal before the Council for Transparency, but it was declared inadmissible sua sponte, because it was not within its subject matter jurisdiction.

A recent landmark administrative decision regarding access to environmental information to file complaints, was Correa vs. SMA ${ }^{124}$. This was a weird case, regarding a 2013 compliance research report on the state-owned Ventanas copper smelter, proactively disclosed by the SMA via its NEEIS platform, but with censored parts. In January, 2017, Ms. Correa filed a disclosure request to access the uncensored report, but the agency refused based on the impairment exception. Then Ms. Correa filed an administrative appeal before the Council for Transparency, stating that the denial was unjustified as no enforcement decision was possible, because it was time-barred as the supposed violation was detected in 2013.

The SMA contended that, as some additional enforcement decisions were pending, to release the censored information would impair its effectiveness; and also, that the detected violation was not time-barred. The Council for Transparency decided that, under the impairment exemption, the agency had to show first that the requested information was indeed an input to future administrative decision-making, and then, that its release would indeed impair its effectiveness. To ascertain if it was really an input, it required that the SMA must show that there was a real intention to decide within a reasonable time, otherwise it could be indefinitely withheld. About reasonable time, it noticed that the 2010 EGRA has a statute of repose of 3-years since the violation happened, 3 years after it had been detected was a very reasonable time to decide.

${ }^{123}$ Council for Transparency, case number C2299-14, 5 November 2014.

${ }^{124}$ Council for Transparency, case number C749-17, 30 January 2017. 
Being so, it decided that the impairment exemption was wrongly used and ordered the release of the uncensored report.

But, once the enforcement proceedings have commenced, some problems with accessing information have also ensued. This issue was first taken to the Judiciary in OHL Inc. v. SMA ${ }^{125}$. In December 2014, the SMA concluded enforcement proceedings against OHL Inc. issuing two administrative fines, one for building a parapet wall in a river to improve a sand extraction pit in violation of its IEP, the other for administrative contempt, as the company ignored an order to destroy the parapet wall. In January 2015, the company filed for judicial review before the 3rd Environmental Court, stating that the SMA denied its request to access some confidential records that were used in its fact-finding decision, thus violating its right to defence and to a fair and due process. The defendant did not contend that some records were kept confidential; but justified its decision stating that those records were shared by the Prosecutor General under confidentiality, as some suspected environmental crimes related to these activities were under investigation. In its August 2015 decision, the Court concluded that, as for the first aforementioned fine, the administrative decision blatantly violated the right to a fair and due process, and so voided it.

A similar controversy ensued in 2015, in Campiche Power Co. Inc. $v$. $S M A^{126}$. In November 2013, the SMA inspected a coal-fired power plants complex owned by the plaintiff, and then again in June 2015. As no compliance research report was posted in the NEEIS platform, in July 2015 the company filed a disclosure request based on the 2003 APA. The SMA handled it as filed under the 2008 FOIA and refused disclosure under the impairment exemption, also citing Hermosilla v. SMA. Then in August 2015, the company filed for judicial review before the 2nd Environmental Court, stating that the SMA acted arbitrarily and capriciously by changing the grounds of its request, from one based in the 2003 APA concerning its procedural rights as an overseen company, to one based on the 2008 FOIA, concerning general transparency. The SMA continued to state that such legal argument must be ignored since it was a request for reactive transparency, even filing a motion to dismiss for lack of subject-matter

125 3rd Environmental Court, case number R-11-2015, 4 August 2015.
126 2nd Environmental Court, case number R-79-2015, 30 May 2016. 
jurisdiction. In its May 2016 decision, the Court sided with the SMA, stating that such decisions must be solely appealed against before the Council for Transparency, as the 2008 FOIA is lex specialis vis-à-vis the 2003 APA and the 2010 EGRA; then the plaintiff filed an appeal before the Supreme Court.

In its August 2017 decision, the Supreme Court decided on Campiche Power Co. Inc. v. SMA ${ }^{127}$, and though it did not reverse the ruling on subject-matter jurisdiction, it did reverse it on its merits, reviewing the case de novo, concluding that the lower court misconstrued the 2003 APA, the 2008 FOIA, and the 2010 EGRA. The decision recalled the impairment exemption under the 2008 FOIA vis-à-vis the right to access the records pending a decision to commence under the 2003 APA. About the impairment exemption, it stated that the company was in a unique position, as it was overseen by an enforcement agency with a limited privilege to kept records secrets to duly perform its functions. As the company could become a defendant if proceedings were commenced, its right to prepare an appropriate defence existed even before such commencement. However, it stated that as the time lapse from the inspection date had increased without any notice of commencement, the company could experience impairment of its right to a defence by worsening its chances to collect evidence on his behalf. The Supreme Court then concluded that to lawfully deny access based on the impairment exemption, the agency must survey the time elapsed since such records were made; as such time increases it would entail a higher justificatory burden to deny access. Thus, corroborating that more than 3 years had elapsed since the inspections, it reversed both the lower court and administrative decisions, granting access to records.

\section{CONCLUSIONS}

As stated before, general public debate is far more complex than environmental debate, and often politicians are worried about many competing concerns under budgetary constraints. Being consistent with

${ }^{127}$ Supreme Court of Justice, case number 41790-2016, 7 August 2017. 
reality, it is noticeable that our elected politicians and appointed officials want to be elected, reelected, appointed, or confirmed, and therefore, in order to achieve it, they need to deliver their promised public policy, and if successful, to claim credit for it. If not, every setback must be avoided or diminished, mistakes must be kept hidden, eventually released in data smog and inserted in blame games.

Freedom of information, transparency, and right to know, can turn into nothing unless mechanisms are available to review administrative decisions denying access to reactive disclosure, or to overcome the agency's failure to comply with proactive disclosure. The impairment and the trade secret exemptions can hinder transparency and public input in environmental-related adjudication and rule-making proceedings.

In Chile, transparency in permitting notice-and-comment adjudication proceedings has no major issues; and in enforcement adjudication proceedings it has some challenges due to a mixture of both flaws in regulatory design and the underfunding of the SMA. Nonetheless, in rule-making notice-and-comment proceedings, the problems are policy-related, since the MMA political success is largely rated by how many regulations are adopted. To speed up these proceedings, some mandatory procedural stages and records are seen as a pure formality. This approach is somewhat similar to the practice of box-ticking identified by McGivern and Ferlie ${ }^{128}$; and also, to the legitimizing strategy detected by the $\mathrm{OECD}^{129}$, to perform regulatory impact assessment in a superficial and a non-transparent manner, only to legitimize a predetermined policy decision rather than to provide evidence.

But both the 2010 EGRA and the 2012 ECA establish specific judicial review actions in these adjudications and rule-making proceedings, and the Environmental Courts have adopted a hard look review approach. By doing so, they become agents of change, and unsurprisingly, to Sir Humphrey Appleby's dismay, they have fought "the right to be ignorant".

${ }^{128}$ See G. McGivern, E. Ferlie, Playing tick-box games: Interrelating defences in professional appraisal, "Human Relations" 2007, vol. 60, p. 1361.

129 OECD, Integrating the environment in Regulatory Impact Assessments, GOV/ RPC(2011)8/FINAL. 